\title{
THE INTERNALIZATION OF ISLAMIC VALUES IN PESANTREN
}

\section{Andewi Suhartini}

Universitas Islam Negeri (UIN) Sunan Gunung Djati Bandung

Jl. A. H. Nasution No. 105 Cibiru, Bandung, Jawa Barat, Indonesia 40614

Email: suhartini_andewi@yahoo.com

\begin{abstract}
This article aims to describe the internalization of Islamic values in fostering akblak (morality) of santri (Islamic boarding school students) in Pesantren (Islamic Boarding School) Miftahul Muhajirin Cidadap, Pagaden, Subang. The Internalization carried out in the forms of religious activities such as fardu prayers in congregation, sunnah prayers Qiyãm al-lail and Duha, sunnah fasting on Mondays and Thursdays, and recite Yasin after dawn. The Islamic internalization process of Islamic values takes several steps namely transformation values; transaction values; and trans-internalization values. The overview of akblak santri from internalization results obtained from questionnaires data distributed to 53 santri. From the questionnaire data, it was obtained the categories of akblak santri; excellent students $(52.83 \%)$, good (45.28\%), and quite good $(1.89 \%)$.
\end{abstract}

Keywords: Akhlak, Internalization, Islamic Values.

\begin{abstract}
ABSTRAK
Artikel ini bertujuan untuk mendeskripsikan internalisasi nilai-nilai islami dalam membina akblak santri di pondok pesantren Miftahul Mubajirin Cidadap, Pagaden, Subang. Internalisasi dilakukan dalam bentuk-bentuk kegiatan keagamaan yang dilaksanakan berupa: shalat fardlu berjamaah, shalat sunnah Qiyãm al-lail dan Dhuha, puasa sunnah Senin Kamis, dan membaca surat Yasin ba'da Subuh. Proses internalisasi nilai-nilai islami menempub langkah transformasi nilai; transaksi nilai; dan transinternalisasi nilai. Gambaran akblak santri hasil internalisasi diperoleh dari data angket yang disebarkan kepada 53 orang santri. Data dari angket, diperoleh kategori akhak santri sangat baik (52,83\%), baik (45,28\%), dan cukup baik (1,89\%).
\end{abstract}

Kata Kunci: Akblak, Internalisasi, Nilai-nilai Islami. 


\section{INTRODUCTION}

Development of information and technology in globalization era that increased rapidly affects almost all aspects of life. Globalization can have positive effects such as ease of access to knowledge and information, ease in meeting the needs, and rapid mobility. However, globalization has also negative impacts, including on the development of adolescent morals. There are some teenage morality declines at a spoken manner, respecting the older people, as well as the fall in promiscuity.

The akblak degradation can not be allowed to continue growing. Necessary efforts should be made to prevent further decline of adolescents morals, including through the application of value to teaching in schools (Hasanah, Gustini, \& Rohaniawati, 2016; Othman, 2016) the integration of the subjects at university or at school (Subarkah, Rahmawati, \& Dalli, 2016; Damana, 2012) and through education in Islamic boarding school (Abdurrahman, 2016; Astuti, 2015; Makmun, 2014; Wulaningsih, 2014).

Pesantren is the oldest Islamic institution growing in this country, and it has a very important role in Indonesia history in Indonesia, pesantren has been proven to be able to create noble generations. In pesantren, the santri obtain a continuous guidance in all the time and covers all dimensions. It is supported by the fact that boarding schools are the traditional educational institution where the santri live together and learn science under the guidance of kiai (Islamic teacher), and it has a place where santri should stay. This place facilitates the head of the pesantren, kiai and teachers to be able to monitor their akblak all the time because the kiai and santri live in the same area. Furthermore, the character development is also supported by the availability of a mosque in the school area as a means of worship, space for reciting, and other religious activities. Another thing that supports discipline and controls the activities of santri, in the vicinity of schools, usually built a fortress to keep out the entry of santri freely. Therefore, they are easily accustomed in any religious activities, recitals and other religious activities (Dhofier, 2011).

The learning process along with togetherness is an interesting side of the property owned by the pesantren. The values of togetherness with the feel of openness of learning, the positioning schools as institutions engaged in the assumption of, for and by the community, because within the scope of the boarding school community can learn together and proceed along only with the conviction that boarding schools are local agencies that have ties togetherness, that is until now a force in the history of the trip boarding schools. Communities and schools like tweedledum and tweedledee are fixed together and intertwined, so that any changes that occur in many other institutions that sank, schools still exist and survive. 
Development of akblak in pesantren can be applied through internalization (Rosyad, 2011; Supriyatno, 2016). Values (akblak) internalization is the process of making value as part of the individual (Soedijarto, 1993). Akblak santri is affected by many factors that can be done by several approaches, strategies and methods of internalization. It means that the growth and development of akblak santri do not stand alone, and not appear by itself or up to fate (given).

The internalization process in each pesantren has its model and advantage. Hence, many researchers conducted the study at various pesantren (Abdurrahman, 2016; Astuti, 2015; Makmun, 2014; Wulaningsih, 2014) this paper presented the results of studies related to Islamic values internalized in fostering akblak santri; the internalization process of Islamic value in fostering akblak santri, and guided the akblak of Islamic boarding school students of Miftahul Muhajirin Subang through the Islamic values internalization. The data was obtained through observation, interviews, and questionnaires.

\section{DISCUSSION}

\section{Akhlak in Islamic Point of View}

In Islam, akblak is the actualization of a personal Islamic and faith. A personal character comes from her or his definition toward the Islamic faith and values attached to the inner attitude. Akblak is the character of someone living in his or him soul that will drive the deeds done easily without any consideration (Al-Ghazali, 2000). People who have a good akblak will do a good deed sincerely without expecting any rewards. Good deeds flowed away without any consideration, except in the name of Allah. While the act is defined as a physical or mental activity that is conscious, deliberate and purposeful. The act may be the motion activity or silence without motion. An act of akblak worth can also be a non-acting and speak throughout the conscious, deliberate and purposeful. People who have high morals will organize actions, speech, and the silence. There are four strengths in someone who has good akblak, namely lust, anger, knowledge, and justice (Al-Ghazali, 2000).

Operationally, akblak has vertical, horizontal and internal dimension. Vertically, akblak explains relationship pattern with Allah. Horizontally, akblak lead lifestyles with human beings and another God's creature. Finally, internally, it leads character patterns with ourselves.

Akblak reinforces the dividing line between those who have moral and those who did not have. Akblak is also the spirit of Islam. Religion without akblak is just as a lifeless body. Fostering human character became one of the apostolic missions of the Prophet Muhammad. In the days of jähilliyyah, 
human morality has collapsed. The previous people have a bad tradition; drinking wine, throwing their child, killing, doing injustice, defeating, bullying weaker people and so on. The conditions described them do not have a certain character, and it makes no difference to people who do not have a religion.

Akblak is a value which guarantees human salvation from the torment of hell fire. People who do not have akblak identified disobedience to Allah and threatened with a painful torment in hell. Akblak indicates the degree of faith, piety, and human wisdom. Akblak became a marker of excess among humans. The perfection of faith, the height of piety and wisdom embodied in the certain person's character.

The position of akblak in Islam is identical with the Islamic religion implementation in all areas of life. Applying a good akblak means performing all religious orders and leaving all the ban of religion, either in the vertical dimension (relationship with Allah), horizontal (fellow creatures) and internal (self). Actions undertaken will be maintained by the rules of religion and belief that Allah is the All-seeing.

\section{Fostering Akhlak Santri in Pesantren}

One of the akblak santri enhancement at pesantren is done through the implementation of Islamic values internalization strategy (Abdurrahman, 2016; Astuti, 2015; Makmun, 2014; Wulaningsih, 2014) and the application of religious habituation practices (Attaran, 2015); Ulwan, 2013). Value internalization is a process to make the value as part of the individual (Soedijarto, 1993). There are some fundamental religious values that should be instilled in children at the core of religious education. Among the values that are fundamental namely: a) iman (faith); b) islam; c) ibsan; d) taqwa; f) Tawakal (resignation); g) syukur (Gratitude); h) sabar (patient) (Madjid, 2000). Islamic values, the essence, captured from 99 attributes of God contained in the al-Qur'an in al-asmã al-busnã, the source of the human conscience (self conscience) including: (a) honesty, (b) equity, (c) the responsibilities, (d) the mandate, (e) hard work, (f) istiqamah, (g) Ikblash, and (h) patience. Islamic values can be internalized through religious practices.

In Islamic values internalization process, there are strategies, approaches, and methods chosen. The models in this strategy are: the traditional strategy, free strategy, reflective strategy and trans-internal strategy (Muhaimin, 2004; Mawardi, 2011; Astuti, 2015). An appropriate strategy for religious values internalization is a trans-internal strategy (Thoha, 1996). The trans-internal strategy is a way to teach the value by doing a transformation of values, proceed with the transaction and trans-internalization. On the strategy of communication trans-internal occurred together between teachers 
and students. Communication involves verbal communication and physical communication, and the inner communication between teachers and students. Teachers provide exemplary, provides examples of values and good deeds attached to him, and serve as a presenter of information. While students receive, and respond to the teacher example (Thoha, 1996).

The process of Islamic values internalization above can be implemented through the habituation method in religious practices. Habituation is a certain behavior doing automatically without premeditation and applied without thinking again (Ramayulis, 2004). Habituation method aims to form the character or personality of learners by fostering good deeds so that in the end the good deeds will be internalized by them.

\section{Islamic values in Pesantren Miftahul Muhajirin Subang}

From the interviews with the head of pesantren (Rukiyah, 2015) and the observations at Miftahul Muhajirin school, it is found the Islamic values internalized by habituation religious practices include: faith, Islam, charity, piety, sincerity, resignation, gratitude, patience, honesty, fairness, responsibility, trustworthy, hard work, steadfastness, solidarity, leadership, discipline and order. The values, then, became the focus of this research.

\section{The Internalization Process of Islamic Values in Fostering Students' Akhlak in Pesantren Mifhatul Muhajirin Subang}

Internalization of Islamic values at Miftahul Muhajirin school done through trans-internal strategy by doing three things: (1) transformation of values, (2) transaction of value; and (3) trans-internalization of value.

\section{Transformation of Values}

At this stage, there are two things performed: (a) Kiai informs the good and the bad values; and (b) Kiai conducts a fundamental change, good appearance, form, nature, function, invention or Diffusion.

a. Kiai Informs Good Values and Bad Values to Santri through Verbal Communication.

The first step done by Kiai in transformation stage is providing information and dissemination of Islamic values to Santri. Kiai explains the concept of Islamic values to santri when they learn the books at-Tijan alDarary, al-akblãk al-Banîn, Nașaih al-Tbãd, Khulãsat Nüril Yaqîn and when the habituation religious practices happened. Kiai provides explanations about values of faith, islam, ibsan, taqwa, ikblas, resignation, gratitude, patience, honesty, fairness, responsibility, amanah, hard work, istiqãmah, solidarity, leadership, discipline, and order. when habituation of congregational fardlu prayer, sunnah praying, Qiyam al-lail prayer, and Duba prayer, Kiai notify the values of faith, islam, charity, piety, and ikblas. Faith value is described as an inner attitude of trust to Allah. Islam value described as a resignation and 
obedience to the rule of God. Ihsan Value is described as the deepest awareness that God is always present with us wherever they are so that we always feel supervised. Taqwa Value is described as an attitude that is conscious that God is always watching over us, so we just do something in the God willingness and always keep ourselves from acts that are not His willingness. Ikblas Value is described as a pure attitude in behavior and acts solely for the sake of obtaining ridha (willingness) of God. Values of solidarity is described as an attitude of togetherness that is strong, with no interest differences. There is only one goal to meet Ilähi Rabbi (God). Through prayers, the society can unite towards one victory (ideals), both in the world and in the hereafter. Leadership value is described as a personal attitude with leader spirit. This is true, for in prayers there is an imam (leader) and also a congregation (people). A ma'mum (congregation) must obey (follow) on his imam (priests), he can't precede the prayer otherwise, it can be fatal. Therefore, the congregation prayers teach the obedience value of ma'mum (congregation) to a leader (imam). The value of discipline and order are described as obedient attitude towards the rules.

Kiai also explained about the harm of kufr (reject to God's Willingness), maksiat (brake the rule), and riya (arrogant). It is described by Kiai that kufr leads a person on denying the existence of God; maksiat plunges someone to disobey of God's command and carry out God's prohibition; whereas riya makes someone proud of himself for all his accomplishments.

The bad and good values are explained in order to make santri understand, so when they do daily prayers, both fardlu and sunnah, it based on their faith; They fully surrender to God; They intend to carry out His orders; And they do these, only, because of God.

When sunnab fasting on Mondays and Thursdays, kiai explain the value of gratitude, patience, honesty, fairness and trust. Gratitude is described as a grateful attitude and appreciation for all blessings and gifts that are innumerable. Patience is described as a patient attitude in facing all the bitterness of life either big and small; outer and inner; physiological and psychological. Honestly is described as a consistent attitude between what someone said and done with the reality. Justice is described as a proportional attitude toward whoever and whatever. Trust is described as reliable attitudes on any assigned to him. Furthermore, kiai also explained about the opposite attitudes of those. There are kufr, haste, lie, and treasonous. These bad values should be shunned and abandoned, because besides forbidden by Allah these, also, will bring madlarat (emergency) for those who do these and the people around them. 
When reciting al-Qur'an (sũrat Yãsin after dawn), Kiai explains the value of steadfastness, hard work and responsibility. These three values described the relationship with the intention of reciting Yãsin every after dawn as the responsibility of a person against himself and his neighbor. It contains the prayers and imploration to the protection from musibab (danger) that might happen.

With explanation and dissemination of Islamic values, santri have a sense and understanding about substance of values, including the significance for their daily behavior.

b. The Effort to Make a Fundamental Change, in the Terms of Form, Characteristic, Function, Invention, or Diffusion.

The second step of the transformation phase of Islamic values is an effort to make a fundamental change in appearance, form, nature, function, Difution or invention. This step is a continuation of the first step described above, in explaining Islamic values contained in any religious practices. In this step, kiai perform non-verbal communication (non-verbal communication) as an effort to fundamental change of students' attitude and behavior. Forms of non-verbal communication among them are gestures, facial expressions, clues, symbols, uniforms, colors and voice tone (Otu, 2015)

In explanation reinforce of Islamic values through verbal communication above, non-verbal communication is very important to consider and do. To make efforts to change students' attitudes and behavior based on Islamic values, in communicating, kiai paid attention on communication timing, gestures and expressions in accordance with the message value that delivered, right tone and intonation, as well as a touch of affection that shown in the communication. This reinforces the message to be received by the deepest heart of the students, so that they are called to make that value as an agent of change to change attitudes and behavior in accordance with the demands of the Islamic values (Rukiyah, 2015).

\section{Transaction of Value}

In this phase, kiai not only gave an information about a good and bad value, but also included to perform and give a sample of real application. The students should follow and apply the sample that was shown by kiai. In transaction phase, there are three things highlighted in this research: (a) The two direction of communication or interaction between santri and kiai that has mutualism content; (b) The kiai inclusion to perform and give the real sample; (c) The respond from santri to receive and apply the values.

a. The two ways communication process (the interaction between santri and kiai which have mutualism content). 
Based on the interviews and observation, the communication process of Islamic values between kiai and santri in this pesantren was conducted with three pattern: verbal communication, written communication (schedule), and practice communication. In verbal communication, the Islamic values were described by kiai in every reciting kitab (religion book) that contained the material. Santri paid attention to the material. When they did the religious activities, kiai showed the habit and attitude that contained the Islamic value and also the santri concernd about it. In Muwãda'ah, it was when santri were going to go home, they were emphasized to have the same attitude and habit as in pesantren. As well as in muwwajjahah, it was when they came back to pesantren, kiai always emphasized the Islamic values in every religious activities and santri used to keep it in their mind.

Moreover, in habitual term, kiai tried to give a good sample in doing religious activities by the Islamic values and santri would follow kiai. What they saw from the kiai habits', they tried to follow it in performing fardlu prayer togetherly, Qiyam al-lail and Duba prayer, sunnab fasting on Monday and Thursday, and reciting holy Qu'ran (sürat Yãsîn after Subub prayer) (Rukiyah, 2015).

b. The kiai involvement to apply and give a real sample.

The next effort done by kiai in the transaction of value phase is their involvement in religious activities and giving a sample to be followed by santri. Kiai tried to do and give an application sample of Islamic values in every religious activities. In congregation fardlu prayer, kiai and senior santri togetherly did the prayer. Kiai took a role as imam and santri became makmum. In Qiyãm al-lail and Duha prayer, kiai and senior santri tried to lead them to do these togetherly. In fasting every Monday and Thursday, kiai used to do it togetherly even kiai did Dawud fasting to give them the sample. Moreover, in reciting sũrat Yãsin after subuh, kiai used to lead them to recite. Together, santri and kiai did the religious activities carefully. The kiai is a sample giver, supporter, and booster in accustoming the religious activities which were directed to apply the Islamic values (Rukiyah, 2015).

c. Santri have responded, received and applied the Islamic values.

The important point that should be empashized in the transaction phase is respons, receiving, and application of santri toward the values. Based on the interview and observation, santri were carefully conditioned in order they could respond everything directed and sampled by kiai. If there was a negative respons, the kiai would responsively tought and directed them to do the religious practice. Finally, by the effort of kiai, santri tried to do it carefully. In congregation of fardlu prayer, santri followed kiai as fast as they can as well as in Qiyãm al-lail and Duba prayer. It was not only by kiai 
enforcement, but also by their iman, ihsan and islam values moreover by their taqwa and ikblas. Therefore, they did it with belief, surrender, awareness and ikblas because of Allah.

In sunnah fasting every Monday and Thursday, santri would also do it togetherly with full of grateful, patient, honest and trusted feeling. They received every direction from kiai carefully, so that they did it without any forces.

In reciting Quran practice, sũrat Yãsin after subuh, santri made a circle in mosque to perform tawașul and continue reciting sürat Yãsin together leaded by kiai or senior santri who had been scheduled to lead the activity.

There were various responses of santri in accordance with their characteristics. However, the strong support and guidance from kiai has delivered them to do all the religious activities so that they realized about the Islamic values within (Rukiyah, 2015).

\section{Trans-internalization}

Trans-internalization actually is to combine the structural change and innovative effort so that the relationship between those values can form the pesantren civilization. Islamic education culture in pesantren is the combination among values, belief, assumption, understanding, and hopes which are taken from Islamic thought and it's trusted by pesantren society and it became a rule in doing something and in solving their problem internally or externally. On the other words, the culture of pesantren is the spirit, attitude and habit of related people to solve the problem they face in consistenly (Mawardi, 2011). In this phase, there were four process, namely: (1) appreciation process inherently among Islamic values so it became an bond of awareness; (2) the process of combining value, belief, assumption, understanding and hope that are taken from Islamic thought and have been believed by someone and have been become their rule to solve the problem; (3) appearance in mental habit and personality not only physical appearance; And (4) communication process between two personalities, kiai and santri in active way. These four things will be discussed below:

a. Appreciation process inherently among Islamic values so it became a bond of awareness.

The first step from trans-internalization value is appreciation process inherently among the Islamic values so that it became a bond of awareness and it can be realized in ethic rule in empowering santri. A value needed an appreciation process inherently to become an awareness that bind the owner. Based on the interview and observation, it was known that in habituation of religious activities either in congregation of fardlu prayer, Qiyam al-lail and Duba prayer, sunnah fasting every Monday and Thursday and reciting Quran 
(sürat Yãsin after subub), the condusive situation was created to help santri to pay fully attention on the values of iman, islam, ihsan, taqwa, ikhlas, tawakal, syukur, sabar, patience, justice, responsibility, amanah, hard work, istiqãmah, solidarity, leadership, disciplinary, and order. Those values were tried to be understood by santri so that it can become their mental attitude that bind their religious activity in daily life. Moreover, santri did the activities simultaneously with their awareness and supported each other.

b. The process of combining value, belief, assumption, understanding and hope that are taken from Islamic thought and have been believed by someone and have become their rule to solve the problem.

In the second phase, the trans-internalization process was done to combine values, belief, assumption, understanding and hope became a sinergyc unity to be believed and to become a guidance to their attitude and to become a solution for their problem. In this step, santri has begun to be trained to manage their personality system adapted with Islamic values that contained in congregation fardlu prayer, sunnah fasting every Monday and Thursday and reciting al-Qur'an (sürat Yãsin after subub), the condusive situation was created to help santri to pay fully attention on the values of iman, islam, ihsan, taqwa, ikhlas, tawakal, syukur, sabar, patience, justice, responsibility, amanah, hard work, istiqãmah, solidarity, leadership, disciplinary, and order. These Islamic values were directed and tought even sampled to be a principle in doing daily activities. Those values can not stand alone separately, they become a rule togetherly in the activities in daily life (Rukiyah, 2015).

c. Appearance in mental habit and personality not only physical appearance.

In this phase, the appearance of kiai in front of santri was not only about physic, but also about mental habit and personality. There were the Islamic values included iman, islam, ihsan, taqwa, ikhlas, tawakal, syukur, patient, honest, justice, responsible, amanah, hard work, istiqãmah, solidarity, leadership, disciplinary, and order. These began to be appreciated by santri so there were the understanding and receiving toward those values. In religious activities practice, these have been trained simultaneously so that the Islamic values became their mental habit. Moreover, those mental habits can reflect in their expression and attitude.

They were conditioned to do congregation of fardlu prayer, Qiyãm allail and Duba prayer with their belief that Allah is the Creator; with their resignation as a slave who should bow and loyal to His order; with being watched feeling by Allah and doing all things because of Allah. They were also conditioned to apply it when they did sunnab fasting every Monday and 
Thursday in order the values of grateful, patient, honest, justice and trusted could reflect and actualize in their attitude.

Similarly in reciting al-Qur'an (sürat Yãsin after subub), santri were trained to actualize the values of istiqãmah, hard work and responsible in their religious activities. It can be shown from some activities that they did; they followed the religious activities very soon on their schedule (Rukiyah, 2015).

d. Two ways active communication between kiai and santri.

The next step from trans-internalization phase is the communication process between two personality (kiai and santri). If the personality has been accustomed with the certain values system and it has been done simultaneously, there would be a unity personality regarding one heart, word and attitude. The Islamic values in religious activities that were accustomed in pesantren namely congregation of fardlu prayer, Qiyãm al-lail and Duba prayer, sunnah fasting every Monday and Thursday, and reciting al-Qur'an (sürat Yãsin after subub), it can be shown in the kiai and santri personality. Kiai and santri did the religious activity togetherly with the same value system that arrange the rule of life in this pesantren. They, togetherly, tried to do all the activities with this Islamic values basic (Rukiyah, 2015).

From the explanation above, it can be described that in this pesantren, the internalization process of Islamic values was performed by kiai with their full of responsibility and love; santri also received it with full of respect and thankful. Moreover, kiai used to respect to the loyalty of their santri; santri also received the reward as the appreciation to improve their loyalty to do their obligation. Kiai, also, used to give warning to their santri when they seemed to be lazy or not to do the activities very soon. Santri seemed to try to receive the warning by changing their attitude and doing the activity very soon.

\section{The Description of akhlak santri from Internalization of Islamic Values in Pesantren Miftahul Muhajirin, Subang.}

One of the purposes of this research is to know the description of akblak santri in pesantren Miftahul Muhajirin Subang from the internalization of Islamic Values gained from the questionaires with Likert scale. The Likert scale was occupied to measure akblak santri based on the values of iman, islam, ihsan, taqwa, ikblas, tawakal, grateful, patient, honest, justice, responsible, trusted, hardworking, istiqãmah, solidarity, leadership, disciplinary, and order. The questionaires consisted of 20 items of positive statements. Every item has the score between 1 until 4 that described disagree (1), less agree (2), agree (3) and really agree. The questionaires were distributed to the 53 santri. The total score gained by every santri, moreover has been categorized become five categories shown in the Table 1. 
Table 1. The Presentage Categories of Questionaires Score

\begin{tabular}{l|l}
\hline Answer (\%) & Description \\
\hline $0-19,99$ & Really disagree (very bad) \\
\hline $20-39,99$ & Disagree (less bad) \\
\hline $40-59,99$ & Enough (neutral) \\
\hline $60-79,99$ & Agree (good) \\
\hline $80-100$ & Really agree (very good) \\
\hline
\end{tabular}

Meanwhile, from the questionnaires, it can be gained the presentage of akblak santri in every category. Table 2 is the presentage data from the questionnaires that described akblak santri in pesantren Miftahul Muhajirin Subang after the internalization process of Islamic Values on every category.

Table 2. Percentage of total santri based on the category of akblak

\begin{tabular}{lcccc}
\hline Category of akblak. & 4 & 3 & 2 & 1 \\
\cline { 2 - 5 } & \multicolumn{4}{c}{$(\%)$} \\
\hline 1. Iman (believe in the existance of Allah). & 53 & 43 & 4 & 0 \\
\hline 2. Ihsan (believe in Allah views') & 53 & 42 & 5 & 0 \\
\hline 3. Islam (resignation to Allah) & 30 & 53 & 17 & 0 \\
\hline 4. Ikblas (perform kbusyu' prayer) & 13 & 38 & 47 & 2 \\
\hline 5. Taqwa (try to avoid bad things) & 4 & 38 & 56 & 2 \\
\hline 6. Ikblas (praying because of Allah) & 23 & 50 & 27 & 0 \\
\hline 7. Tawakal (resignation to Allah) & 8 & 47 & 34 & 11 \\
\cline { 2 - 5 } & 13 & 36 & 47 & 4 \\
\hline 8. Grateful & 37 & 47 & 16 & 0 \\
\hline 9. Patient & 23 & 62 & 13 & 2 \\
\hline 10. Honest & 2 & 55 & 32 & 11 \\
\hline 11. Justice & 4 & 25 & 60 & 11 \\
\hline 12. Responsible & 4 & 25 & 57 & 14 \\
\hline 13. Trusted & 0 & 55 & 43 & 2 \\
\hline 14. Hard Work & 6 & 28 & 58 & 8 \\
\hline 15. Istiqämah & 6 & 62 & 30 & 2 \\
\hline 16. Solidarity & 8 & 43 & 43 & 6 \\
\hline 17. Responsible & 25 & 55 & 20 & 0 \\
\hline 18. Discipline & 4 & 51 & 45 & 0 \\
\hline 19. Order & 0 & 36 & 62 & 2 \\
\hline
\end{tabular}

The total average score of akblak santri in pesantren Miftahul Muhajirn after the internalization process of Islamic Values was done showed that there were 28 santri $(52,83 \%)$ who have the description of very good akblak, 
there were 24 santri (45,28\%) who were in good category, and one santri $(1,89 \%)$ who was in enough category.

The most visible akblak santri were iman and ihsan, it was shown by santris attitude which was really confidence and believe that Allah is exist and Allah is the Watcher. Akblak lived in santris heart after transformation; transaction and trans-internalization process were done. Many santri with iman and ibsan akblak because in internalization process, kiai has given the information and socialization about Islamic values, and also made a basic change either about form, attitude, function, invention or diffusion when they learned at-Tüãn al-Darary, al-akblãk al-Banîn, Nașaỉ al-Tbãd, Khulāṣat Nüril Yaqin and when they were accustomed with religious activities, either congregation of fardlu prayer, qiyammullail prayer and dluha prayer. In value transaction phase, kiai did two ways communication process or the interaction between santri and kiai that contained mutual advantages; included to perform and give the real sample; and santri resp onded, received and applied the values. In this trans-internalization of values process, kiai did the appreciation process inherently mong the Islamic values so that it could be a tight awareness; combining the values, belief, assumption, understanding, hope, that were taken from the Islam thought and have been believed by somebody and also have been a rule to their attitude and their problem solving; the mental performance and personality, not only physically; and the communication of the two personalities (kiai and santri).

While akblak santri that are still in the poor category is the aspect of leaving the injustice against friends, trust and surrender to God, justice, responsibility, hard work, solidarity, and orderly. The number of santri who are less implement Islamic values was caused by less than optimal transformation processes, transactions and trans-internalization against these values. At this stage of the value transformation, kiai less concreted information and dissemination of Islamic values to santri and the lack of strong impetus from kiai to santri to make a fundamental change, good appearance, form, nature, and function, invention or diffusion upon reviewing the book of at-Tijann al- Darary, al-akblãk al-Banîn, Nașaih al-Tbãd, Khulāsat Nüril Yaqin and at the time of habituation of religious practice, both fardlu prayers in congregation and praying sunnah, Qiyãm al-lail and Duba prayer. Understanding and awareness of students against Islamic values become less than optimal. At this stage of the transaction value, communication occurs between santri and kiai who are less reinforce these values, in addition to the lack of reciprocal; Kiai not yet fully engaged in implementing and giving examples of real practice; and the response, the reception and the efforts of santri to practice the value that was less than optimal. At this stage of trans-internalization value, Kiai has difficulties to 
make the process inherently appreciation between Islamic values to be awareness binding, because the level of appreciation were still limited and it took a long time to proceed.

To overcome this situation, it is needed to optimize the three processes. In the process of values transformation, it needs to clarify the explanation of these values so that santri will understand. In the process of the values transaction, it needs a concrete model that is consistent and committed that can stimulate them to respond positively. In value transinternalization, the appreciation systems are needed to easily facilitate meaning to these values.

\section{CONCLUSION}

Based on the description above, the writer can draw conclusions as follows: the values (akblak) that was internalized in pesantren Miftahul Muhajirin included: iman, islam, ibsan, taqwa, ikhlas, tawakal, grateful, patient, honest, justice, responsible, trusted, hard work, istiqamah, solidarity, leadership, disciplinary, and orderly. The internalization process of Islamic values in fostering morality of santri in pesantren Miftahul Muhajirin Subang done through trans-internalization strategy by taking three steps, namely (1) The transformation of values, namely; kiai informed the good and bad values; and kiai tried to make the substantial change, good appearance, form, nature, function, invention or diffusion; (2) the transaction value, namely; the process of two-way communication or interaction between santri and kiai who are reciprocal; kiai engaged to implement and give examples of real practice; and the santri responded, accepted and practiced the value of it; (3) transinternalization value, that is: the inherent process in appreciation of Islamic values so that it becomes binding awareness; the process of integrating the values, beliefs, assumptions, understanding, hope, taken from the core teachings of Islam and believed by someone and used as guidelines for behavior and solving the problems encountered; appearance in aspects of mental attitude and personality, not just physical; and (4) the communication process between two personalities (kiai and santri) actively.

\section{BIBLIOGRAPHY}

Abdurrahman, N. H. (2016). Character education in islamic boarding school based sma amanah. Jurnal Pendidikan Islam, 2(2), 287-305. Retrieved from https://doi.org/10.15575/jpi.v2i2.791

Al-Ghozali. (2000). Mengobati penyakit hati tarjamah ibyã 'ulũm ad-dîn dalam tahdఇৃ̂́b al-akblãq wa mu'ãlajat amrãdh al-qulüb. Bandung: Karisma. 
Astuti, R. F. (2015). Internalisasi nilai-nilai agama berbasis tasawnf di pondok pesantren salafiyah al-qadir sleman yogyakarta. Yogyakarta: Universitas Islam Negeri Sunan Kalijaga.

Attaran, M. (2015). Moral education, habituation, and divine assistance in view of ghazali. Journal of Research on Christian Education, 24, 43-51. Retrieved from https://doi.org/10.1080/10656219.2015.1008083

Damana, A. (2012). Internalisasi nilai tauhid dalam pembelajaran sains. Jurnal Pendidikan Islam, 17(1), 66-84. Retrieved from https://doi.org/10.15575/jpi.v27i1.496

Dhofier, Z. (2011). Tradisi pesantren studi tentang pandangan hidup kyai. Jakarta: LP3S.

Hasanah, A., Gustini, N., \& Rohaniawati, D. (2016). Cultivating character education based on sundanese culture local wisdom. Jurnal Pendidikan Islam, 231-253. Retrieved from https://doi.org/10.15575/jpi.v2i2.788

Madjid, N. (2000). Masyarakat religius membumikan nilai-nilai islam dalam kehidupan masyarakat. Jakarta: Erlangga.

Makmun, H. R. (2014). Pembentukan karakter berbasis pendidikan pesantren. Cendikia, 12(2), 211-238.

Mawardi, I. (2011). Transinternalisasi budaya pendidikan islam: membangun nilai etika sosial dalam pengembangan masyarakat. Hunafa : Jurnal Studia Islamika, 8(1), 27-52.

Muhaimin. (2004). Paradigma pendidikan islam: upaya mengefektifkan pendidikan agama islam di sekolah. Bandung: Remaja Rosdakarya.

Othman, M. (2016). Pembentukan akhlak pelajar menerusi aplikasi teknikteknik penerapan nilai dalam pengajaran. The Online Journal of Islamic Education, 4(1), 58-70. Retrieved from http://ejournal.um.edu.my/public/article-view.php?id=9106

Otu, N. (2015). Decoding nonverbal communication in law enforcement. Salus Journal, 2(3), 1-16. Retrieved from http://www.salusjournal.com/wpcontent/uploads/sites/29/2015/06/Otu_Salus_Journal_Issue_3_Numb er_2_2015_pp_1-16.pdf

Ramayulis. (2004). Ilmu pendidikan islam. Jakarta: Kalam Mulia.

Rosyad, I. M. (2011). Proses pembelajaran di pondok pesantren islam al-irsyad salatiga dalam internalisasi nilai mata pelajaran aqidah pada santri. Surakarta: Universitas Sebelas Maret.

Rukiyah, Y. (2015, Mei 10). Nilai islami di ponpes muhajirin. (A. Suhartini, Interviewer).

Soedijarto. (1993). Menuju pendidikan nasional yang relevan dan bermutu. Jakarta: Balai Pustaka. 
Subarkah, C., Rahmawati, R., \& Dalli, A. (2016). Internalizing islamic values in electrochemistry learning. Jurnal Pendidikan Islam, 2(2), 270-286. Retrieved from https://doi.org/10.15575/jpi.v2i2.790

Supriyatno, T. (2016). The implementation of akhlaq leadership in elementary islamic excellent schools in malang indonesia. Abjadia Internatioonal journal of Education, 1(1), 37-47. Retrieved from https://doi.org/10.18860/abj.v1i1.3271

Thoha, C. (1996). Reformulasi filsafat pendidikan islam. Yogyakarta: Pustaka Pelajar.

Wulaningsih, S. (2014). Peran pondok pesantren assalafiyyah dalam membentuke. karakter santri di desa wisata religi mlangi. Yogyakarta: UIN Sunan Kalijaga. 